REVIEW

\title{
A COMPARATIVE STUDY OF COITAL PHYSIOLOGY, WITH SPECIAL REFERENCE TO THE SEXUAL CLIMAX
}

\author{
G. A. FOX* AND BEATRICE FOX \\ *176 Charlton Road, London, S.E.7, and Guy's Hospital, London
}

(Received 28th November 1969)

\begin{abstract}
Summary. This review attempts a critical evaluation of experiments dealing with the process of coitus, and highlights the features which are common to many mammalian copulations. Data for blood pressure changes in the dog and bitch during coitus have been re-analysed and compared with findings for the human. Four criteria for orgasm are suggested, and these are traced through the mammalian kingdom for possible similarities. The question of female climax is discussed and its temporal and qualitative aspects are outlined in relation to the male climax.
\end{abstract}

\section{INTRODUCTION}

The literature on mammalian reproduction is extensive but contains little on the subject of the sexual climax. It is the intention of this review to establish criteria for orgasm which may be measured in both male and female human and subhuman mammals.

Whilst orgasm and the ejaculation of spermatozoa are clearly related in the male, orgasm in the female is not clearly associated with any conceptive function. If we exclude seminal emission, we are left with a series of events common to both sexes, though even in the case of ejaculation, there may be comparable phenomena in the female genital tract which facilitate sperm transport.

Considered from this viewpoint, the process of coitus with the subsequent climax may be profitably studied in both sexes in human and sub-human species. If we apply our criteria to other mammals, we may find physiological correlates which throw light on human processes of conception. It is our contention that what is subjectively termed orgasm in the human has certain physiological and objective counterparts in sub-human mammalian species. The psychological interpretation of the word orgasm, as applied to the human, does not enter into this discussion.

The following physiological criteria for orgasm are, therefore, proposed:

(1) Changes in blood pressure, respiratory pattern and heart rate.

(2) Changes in muscular tension (including vaginal and uterine contraction). 
(3) Hormonal changes.

(4) Emission of sound.

These criteria will be considered in relation to the literature on human and other mammalian species. Each instance is suggestive of the fact that the sexual climax, or even orgasm, is not a specifically human phenomenon.

\section{CHANGES IN BLOOD PRESSURE, RESPIRATORY PATTERN AND HEART RATE}

Human experiments were conducted by Klumbies \& Kleinsorge (1950), who noted a rise in systolic and diastolic blood pressure and changes in respiratory movement and frequency during extra-coital orgasm in both sexes. Experiments during human coitus have been reported by Mendelsohn (1896) and Boas \& Goldschmidt (1932) who noted an increase in heart rate, and by Bartlett (1956), who reported respiratory changes and an increase in heart rate. Recently, Fox \& Fox (1969) haveshown an increase in systolic blood pressure and a characteristic respiratory pattern during human orgasm.

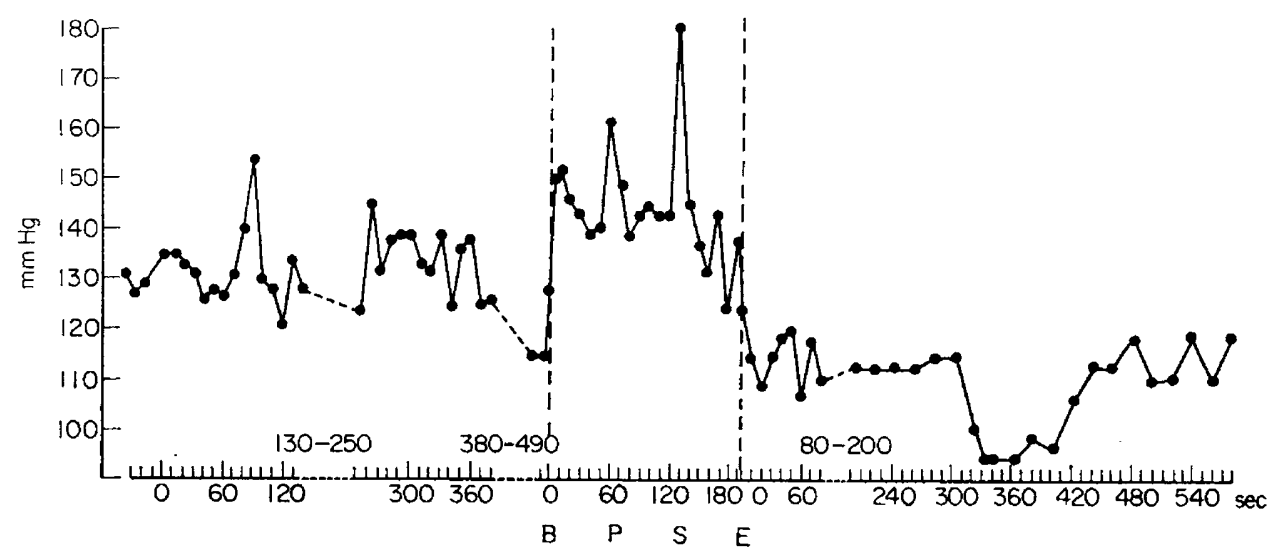

Text-fig. 1. Bitch, Exp. 1. Blood pressure during coitus (based on readings of Pussep). $\mathbf{B}=$ beginning of coitus; $\mathbf{P}=$ positional change by dog (Pussep states that this is the moment of ejaculation); $S=$ movement suggestive of separation; $E=$ end of coitus. Dotted lines are placed where readings are not given in Pussep's Table. The time scale shown in Text-figs. 1 to 3 follows the convention of Pussep. Vertical dotted lines show actual period of coitus.

Pussep (1922) studied the effect of coitus on the blood pressure of dogs and bitches. These results are shown graphically in Text-figs. 1 to 9. Pussep's results are in tabular form in the original, and as precise a graphic representation of his findings is not to be found elsewhere. Kinsey, Pomeroy, Martin \& Gebhard (1953) have drawn graphs of Pussep's data, using a time scale of minutes. Our own independent translations are in close agreement with their graphs. Bishop (1961) supplies a graph of one of Pussep's experiments, but many of the readings have been omitted. Thus, events lasting a number of seconds, which could include orgasm or the effects of ejaculation, might have been missed. 


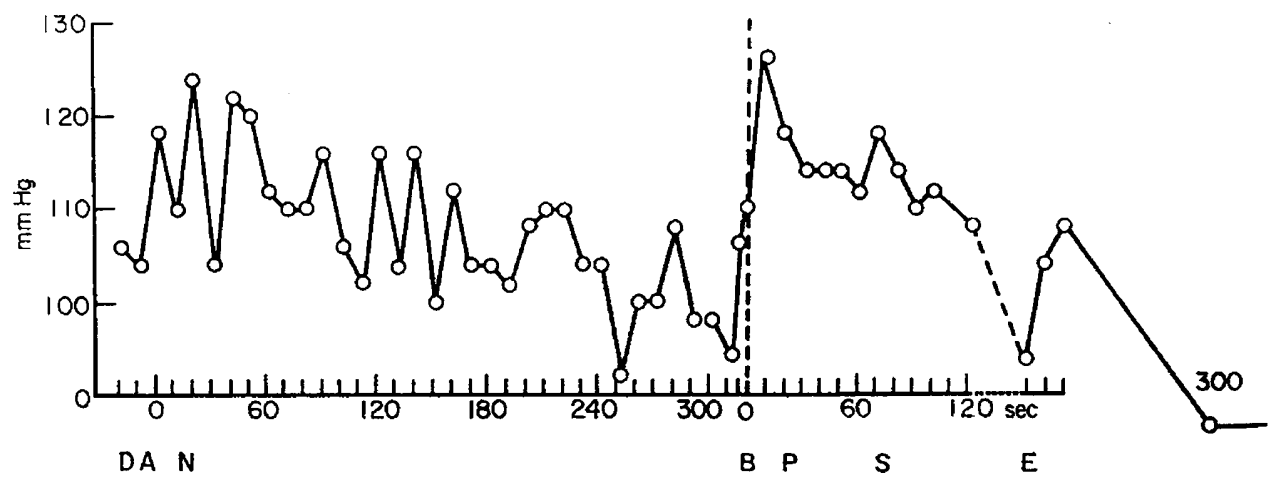

TExT-FIG. 2. Bitch, Exp. 2. Blood pressure during coitus (based on readings of Pussep). $\mathrm{DA}=\operatorname{dog}$ arrives; $\mathrm{N}=$ nuzzling; $\mathrm{B}=$ beginning of coitus; $\mathrm{P}=$ positional change (= ejaculation); $\mathbf{S}=$ movement suggestive of separation; $\mathbf{E}=$ end of coitus.

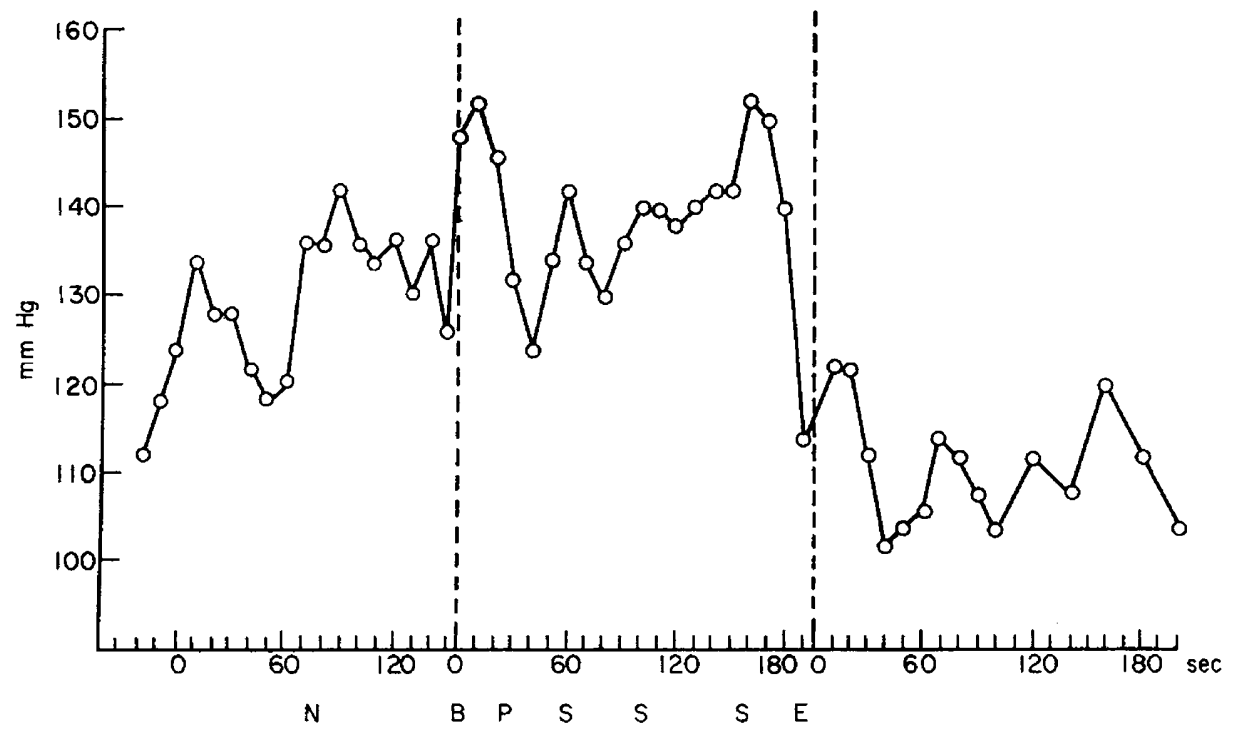

Texr-Fig. 3. Bitch, Exp. 3. Blood pressure during coitus (based on readings of Pussep). $\mathbf{N}=$ nuzzling; $\mathbf{B}=$ beginning of coitus; $\mathbf{P}=$ positional change (= ejaculation); $\mathrm{S}=$ movement suggestive of separation; $\mathbf{E}=$ end of coitus.

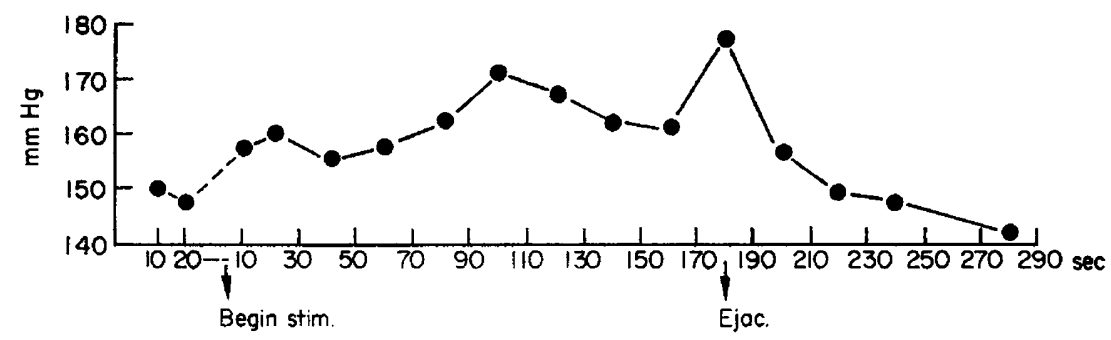

TEXT-FIG. 4. Blood pressure in dog during stimulation (not coitus) (based on reading of Pussep). 
It was on the basis of Pussep's experiments that Ford \& Beach (1951) wrote: "We conclude from this record that the female's physiological response consists of a more or less steady state of arousal not marked by any climactic event and dependent primarily upon vaginal stimulation". Their conclusion once again

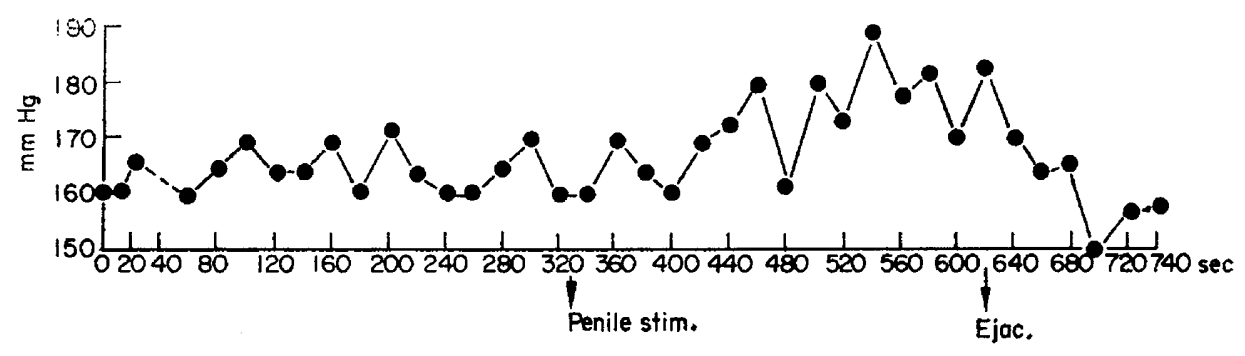

TEXT-FIG. 5. Blood pressure in dog during stimulation (not coitus) (based on readings of Pussep).

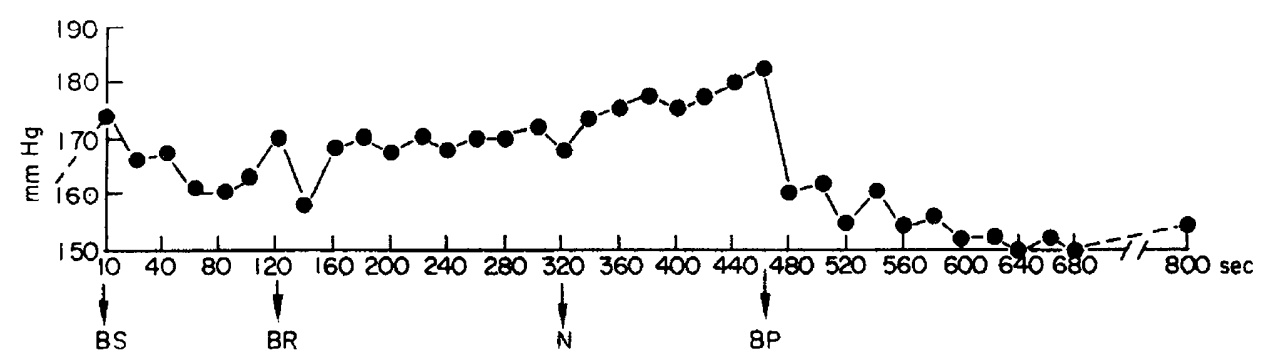

TEXT-FIG. 6. Blood pressure in dog incomplete coitus (based on readings of Pussep).

$\mathrm{BS}=$ bitch seen; $\mathrm{BR}=$ bitch returns; $\mathrm{N}=$ nuzzling; $\mathrm{BP}=$ bitch parts.

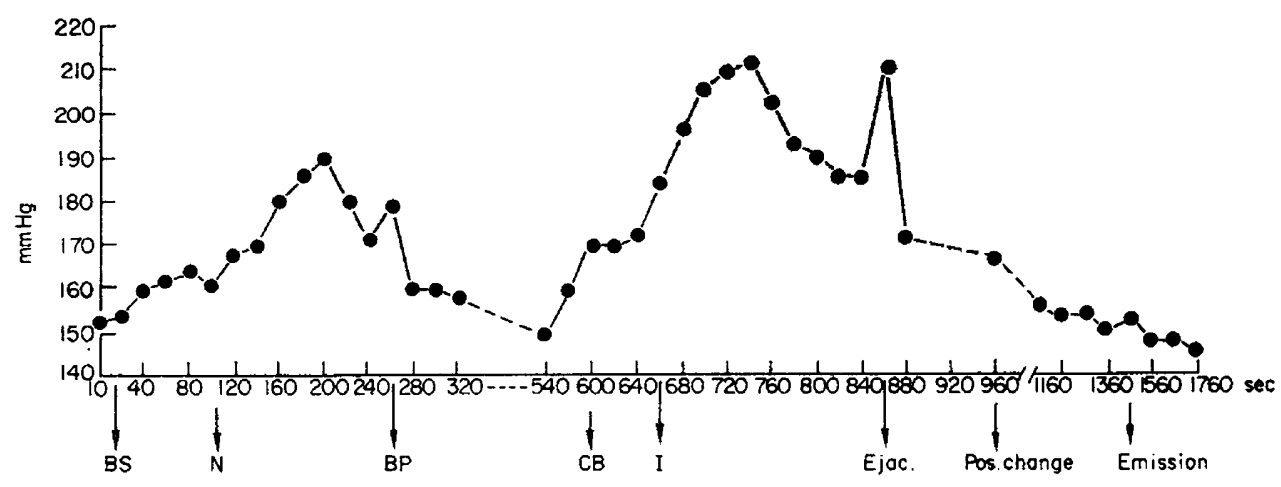

TEXT-FIG. 7. Blood pressure in dog during coitus (based on readings of Pussep). BS = bitch seen; $\mathrm{N}=$ nuzzling; $\mathrm{BP}=$ bitch parts; $\mathrm{CB}=$ coitus begins; $\mathrm{I}=$ intromission.

derives from a telescoping of the original results. They show, graphically, the third of Pussep's experiments on the bitch, but use certain readings from his table whilst neglecting others. The true nature of the curves is, therefore, not revealed. This only became apparent to us when we plotted all the readings in the original table. We were induced to repeat this experiment in the 
human, using a continuous blood pressure recorder, and the results are shown in Text-figs. 10 and 11.

Two of the three experiments of Pussep on the bitch (Text-figs. 1 and 3)

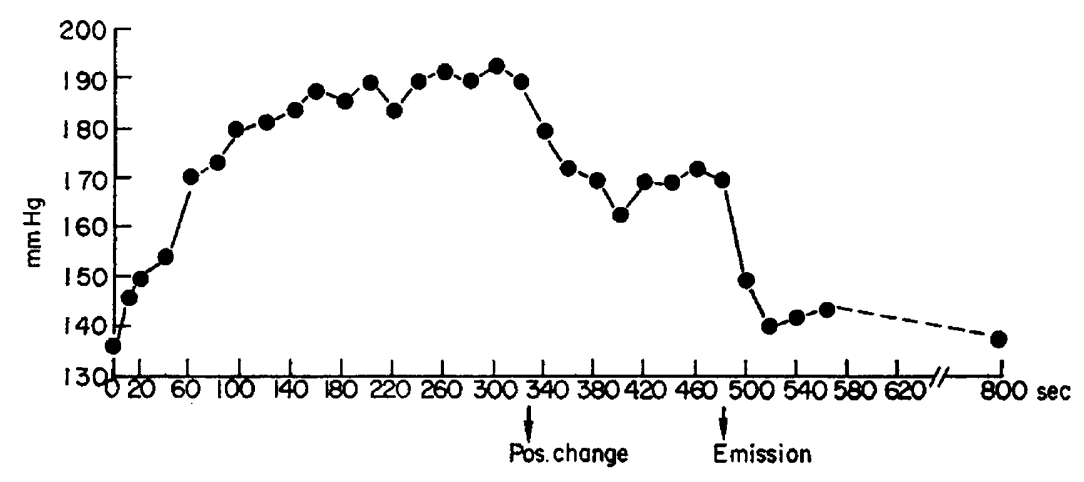

Text-rig. 8. Blood pressure in dog during coitus (based on readings of Pussep).

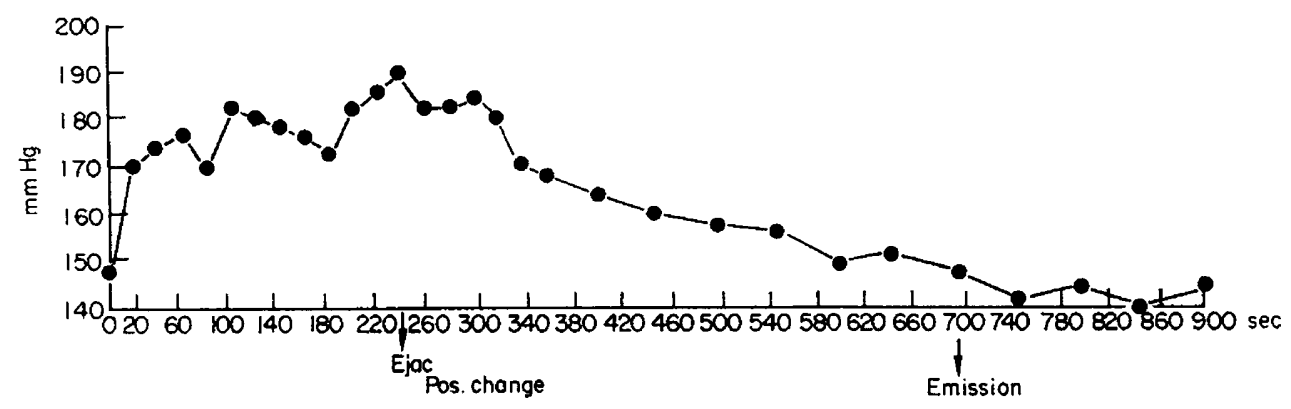

Texr-Fig. 9. Blood pressure in dog during coitus (based on readings of Pussep).

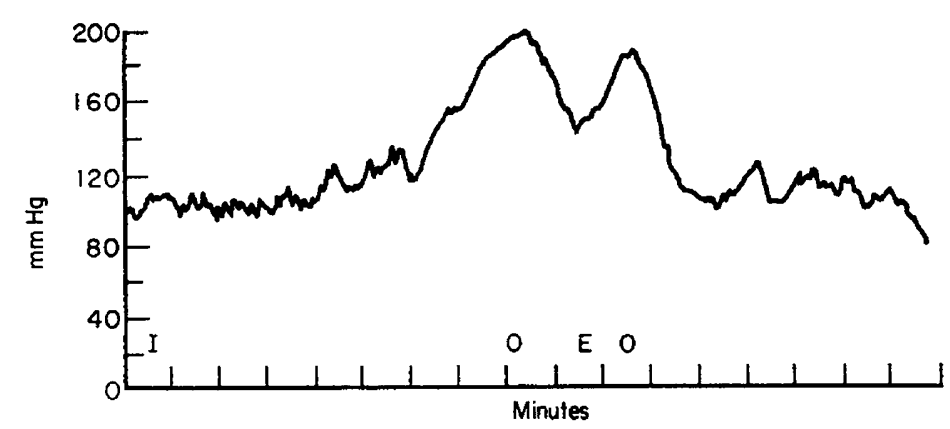

TEXT-FIG. 10. A recording of systolic blood pressure during coitus in one human female subject. $\mathrm{I}=$ intromission achieved; $\mathrm{O}=$ female orgasm; $\mathrm{E}=$ ejaculation.

compare with the human female recording (Text-fig. 10) in the following respects:

(1) There is more than one climactic peak for the female (which, in the human experiment, corresponded with orgasmic experience).

(2) A final peak of blood pressure occurred in the bitch some time after 
ejaculation and at the point of separation (possibly representing a climactic event in the bitch which could cause separation by ejection of the inert penis. Pussep noted that "At each attempt by the dog to separate himself from the bitch, a significant effect could be observed on the blood pressure, being accompanied by a rise in the general blood pressure.").

The findings for the male dogs during coitus (Text-figs. 7 to 9) compare closely with the findings for the human male (see Text-fig. 11), and with those of Klumbies \& Kleinsorge (1950), since the blood pressure rise is of a similar order and there is a peak (two peaks in the first dog coitus experiment) at ejaculation, followed by a very sudden drop in blood pressure.

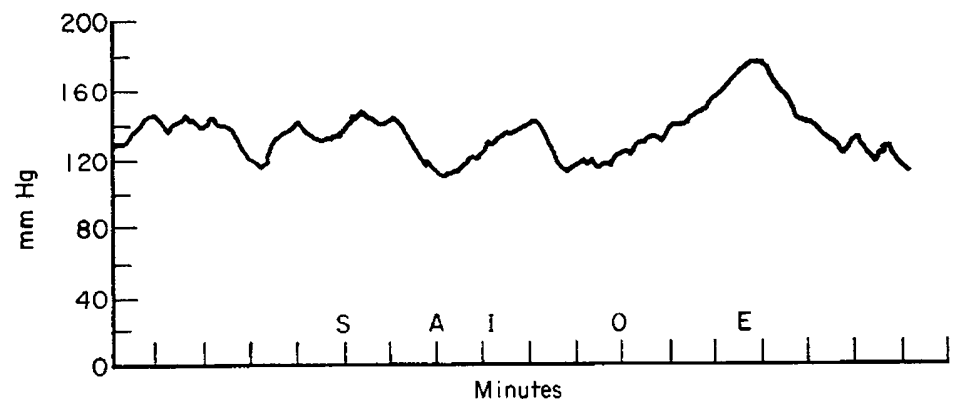

Text-Fig. 11. A recording of systolic blood pressure during coitus in one human male subject. $\mathrm{S}=$ start of timing; $\mathrm{A}=$ attempted intromission; $\mathrm{I}=$ intromission achieved; $\mathbf{O}=$ female orgasm; $E=$ ejaculation.

\section{GHANGES IN MUSCULAR TENSION (INCLUDING VAGINAL AND UTERINE CONTRACTIONS)}

Evans (1933), studying the mechanism of sperm transport within the canine uterus during coitus, used a uterine fistula technique to observe the ejaculate. He observed that between 25 and $50 \mathrm{sec}$ after ejaculation, semen was expelled in regular spurts from the fistula in the uterus. His description of the events was: "... strenuous abdominal muscle straining by the female commences. After each straining, semen will be forced out of the fistula in small streams often to a distance of 20 to $25 \mathrm{~cm}$ (as in forcing fluid from a tuberculin syringe)". Evans suggested that this response might be due to uterine activity or orgasm in the bitch, though he felt that he had insufficient evidence to refute the hypothesis that such a reaction could be due to direct ejaculation into the uterus. We feel that the latter hypothesis does not do justice to his findings since with direct ejaculation into the uterus, the spurts from the fistula should have coincided exactly with ejaculation and not commenced some $30 \mathrm{sec}$ later, or, in some cases, up to 125 sec later.

This experiment was the culmination of previous work along the same lines by Reynolds (1930) and Florey \& Walton (1932). Hartman \& Ball (1930) made similar investigations in rats, but, as their animals were killed within seconds of ejaculation in order to facilitate examination, uterine activity was inferred rather than observed. Spermatozoa were present in the vagina but not in the uterus $30 \mathrm{sec}$ after ejaculation. By $60 \mathrm{sec}$, they were present in the 
uterus. After $2 \mathrm{~min}$, spermatozoa were found in the Fallopian tubes, indicating the rapid passage of spermatozoa through the reproductive tract in this species. Similarly, VanDemark \& Moeller (1951) showed that, in the cow, a distance calculated to take $1 \frac{1}{2} \mathrm{hr}$ on the basis of an estimate of sperm motility was actually accomplished in 2 to $3 \mathrm{~min}$. Colmeiro-Laforet (1953), in an article dealing with lack of orgasm as a cause of sterility, summarized the experiments dealing with the transport of various substances into the uterus during, and as a result of, coitus. The main inference in these experiments was that only uterine contraction would account for the speed of sperm transport and progress in the female genital tract. Further support for this theory comes from the work of Krehbiel \& Carstens (1939), who showed that, after artificial stimulation of the vulva of rabbits, substances such as methylene blue, janus green and iodochlorol were rapidly transferred from the vagina to the uterus. They concluded that the combined activity of the vagina and uterus were responsible for this transportation. Millar (1952) reported a strong negative uterine force during mating of the mare. He connected the uterus to a bottle of methylene blue and noted a strong 'insuck' of this fluid, $80 \mathrm{mI}$ being drawn into the uterus within $5 \mathrm{sec}$. Yamanaka \& Soderwall (1960) demonstrated rapid transport of spermatozoa through the genital tract of the hamster. Spermatozoa were observed in the ampulla (cranial end) of the uterus $91 \mathrm{sec}$ after mating. Akester \& Inkster (1961) studied the passage of radio-opaque material in the rabbit, both during mating and upon genital stimulation, by means of cine-radiography. They concluded that spermatozoa may be carried passively through the cervix and that this process could occur independently of mating. They believed that the "dramatic vaginal contractions associated with mating are concerned mainly with the transport of semen from the site of deposition during coitus, to the cranial end of the vagina". The strongest evidence for uterine contractions during coitus comes from the work of VanDemark \& Hays (1952) on the cow. By the use of an intra-uterine balloon, they showed that contractions reached a peak 15 to $30 \mathrm{sec}$ after the bull had ejaculated, though this time might be reduced to as little as $9 \mathrm{sec}$ on occasions. The use of an intra-uterine balloon has been criticized by Bickers \& Main (1941) on the grounds that the balloon itself might be capable of instigating the contractions. Comparing VanDemark \& Hay's data for oestrous and post-oestrous cows, it seems that this criticism is invalid since the balloon should not affect cows at different stages of the oestrous cycle in different ways. Furthermore, if contractions are related to the artifact of having a balloon in the uterus, there is no reason why the peak of activity recorded should occur at the significant point after ejaculation. Hartman (1957) suggested that the uterine activity in these cows is due to orgasm.

Many of these experiments have been justly criticized on the grounds that fistulae and inert substances create artificial situations. The question of sperm transport has been reviewed by Parkes (1960a), Bishop (1961) and by Fitzpatrick (1966), the latter author giving a comprehensive table on the rate of sperm ascent in the female genital tract. Fitzpatrick's table lists experiments on the mouse, rat, guinea-pig, hamster, dog, rabbit, cow, sheep, pig, and on man. It reveals that there is a species difference in the rate of sperm transport, and in the rabbit, for example, the rate of travel is relatively slow (3 to $6 \mathrm{hr}$ 
to the oviduct). The physiological significance of rapid transport is questioned since, in many species, fertilization is delayed many hours post coitum either because the spermatozoa must undergo capacitation or because the arrival of ova in the Fallopian tube is delayed. We would suggest, however, that rapid transfer of spermatozoa from vagina to uterus may remove them from the more hostile environment of the vagina, and may prevent wastage due to leakage from the vagina post coitum when a vaginal plug is not formed. Moreover, a close perusal of Fitzpatrick's table reveals that it is the journey to the oviduct which appears to be slow, whereas entry of spermatozoa or experimental material into the uterus occurs in a matter of minutes.

Attempts to evaluate the passage of experimental material in the human female genital tract have been made. Von Amersbach (1930) and Trapl (1943) reported the passage of a suspension of carbon particles and carmine particles, respectively, into the human uterus after coitus. However, neither of these experiments is well documented. Egli \& Newton (1961) placed carbon particles suspended in $30 \%$ dextran into the vagina in three anaesthetized women who were about to undergo elective abdominal hysterectomy at about the time of ovulation. At the same time, an intramuscular injection of 10 units of oxytocin was administered. In two of the three women, carbon particles were recovered from the Fallopian tubes 28 and 34 min later. The authors inferred that activity of the uterus, spontaneous or aided by oxytocin, was responsible for the rapid transfer of these particles.

On the other hand, Walton (1930), and Carleton \& Florey (1931), failed to demonstrate the passage of pigment in experiments with rabbits and dogs, respectively. Genell (1939), working with rats, cast doubt on the theory of uterine insuck, and postulated a plunging mechanism in which ejaculated semen is "flung into the uterus". Since he used a cannula to distend the cervix, one may criticize this experiment as differing from the natural situation. Noyes, Adams \& Walton (1958) could not demonstrate the passage of radio-opaque oil or spermatozoa from vagina to uterus in rabbits which were artificially stimulated. They concluded that the spermatozoa entered the uterus by virtue of their own motility.

Grafenberg (1950) and Masters \& Johnson (1966) repeated this sort of experiment in the human, but were unable to demonstrate the entry of radioopaque fluid from a cervical cap into the uterus after coitus and clitoral stimulation, respectively. Fox \& Fox (1967) have criticized this latter experiment on the grounds that it was not performed under natural coital conditions. Recently Fox, Wolff \& Baker (1970) have conducted experiments in the human, using a pressure-sensitive radio-pill to measure changes in intra-vaginal and intra-uterine pressure during coitus. They have shown that pressure on the abdomen by the hand, or in the coital situation by the male lying on the female, increased the intra-uterine pressure by some $10 \mathrm{~cm} \mathrm{H}_{2} \mathrm{O}$. In addition, the presence of the penis alters the state of the intra-vaginal pressure. Such factors cannot be taken into consideration in non-coital experiments. The human experiments with the radio-pill have shown that there is a positive intrauterine pressure during coitus (maximum, $+40 \mathrm{~cm} \mathrm{H}_{2} \mathrm{O}$ ), and a negative intrauterine pressure immediately after female orgasm $\left(-26 \mathrm{~cm} \mathrm{H}_{2} \mathrm{O}\right)$. This confirms 
that the human uterus contracts and relaxes during coitus, as in other mammals, and lends support to the theory of uterine insuck.

The various changes in muscular tension already described may or may not indicate a sudden climactic event in the female, but they do suggest that the female is not completely passive during coitus. The explosive nature of the orgasm in the human female may have its counterpart in a less violent and, therefore, less obvious climax in lower mammals. This is supported by the fact that the human female is capable of several orgasms in fairly rapid succession while the male experiences only one orgasm. This would appear to be related to the different functions of the orgasm in each sex.

\section{HORMONAL GHANGES}

Hormonal changes may be considered both as an expression of orgasmic desire (and heat) and specifically during the act of coitus.

\section{(a) Hormonal changes as an expression of orgasmic desire}

Young (1961) has reviewed this topic and has shown that the effect of castration on sexual desire and drive has been closely studied, particularly in the rat and guinea-pig. There has been a shift of emphasis over the years from the importance of psychological factors to the importance of hormonal mechanisms. This may be commensurate with the improvement in techniques of hormonal assay.

Most studies have relied on the procedure of observing normal sexual behaviour for a species and tabulating a series of events leading to ejaculation, and then comparing the same species after castration. Importance is placed on the precise meaning of the words 'copulation' and 'copulatory activity', for there is little uniformity in the literature. Young \& Grunt (1951) attempted to classify the mating behaviour of the guinea-pig and their definition and classification of the sequence of events is most helpful for comparative studies. In general, it is concluded that "there is a gradual but conspicuous decrease in mating behaviour following castration of such laboratory mammals as the rat, guineapig, rabbit, hamster and cat. However, the pattern of behaviour still contains some of the mating reactions up to and including various degrees of mounting".

Turning to more sophisticated mammals, Michael, Herbert \& Saayman (1966) observed that there was impairment of male orgasmic response or ejaculation in the rhesus monkey, following injection of progesterone into the female. This could have an olfactory basis, but Heller, Laidlaw, Harvey \& Nelson (1958) found that administration of progestational substances decreased sperm count and libido in human males. It is noteworthy that some women taking the contraceptive pill have complained of loss of libido, and it would be of interest to know whether there is any effect on male libido despite the fact that the male partner is not taking the tablets. Further observations were made by Zumpe \& Michael (1968) on the climactic response of the female rhesus monkey in relation to injections of oestrogen and progesterone and at various times during the menstrual cycle. The 'clutching response', which they believe to be an indicator of orgasm in this species, was distinctly related 
to high levels of oestrogen in the female and occurred in every copulation at mid-cycle in this animal. Michael \& Zumpe (1970) have recently brought forward further evidence of rhythmic changes in the copulatory frequency of rhesus monkeys which relate well to the findings of Udry \& Morris (1968) for a human population. The latter authors showed that orgasmic desire was most intense at mid-cycle.

Our own observations (unpublished) over the past 10 years concur with this. We have also noted periods of intense orgasmic desire during pregnancy (four pregnancies), not earlier than the 10th week. This would be at a time when oestrogenic levels were beginning to increase. Two observations by Masters \& Johnson (1961, 1966) offer further corroborative evidence. Firstly, they noted an increased vaginal responsiveness and lubrication in their subjects at certain times in the cycle and secondly, they described the different orgasmic reaction during the second trimester of pregnancy; at this stage the orgasm was less effective in relieving sexual tension, or in other words, the desire for orgasm persisted after the event. They have described the sexual drive as being particularly high at this time. Sexual drive during pregnancy occurs in lower mammals, since rabbits and hares, as well as primates, are known to copulate during pregnancy (Hammond \& Asdell, 1926; Young, 1961). These findings relate to the general knowledge concerning 'heat' and oestrogen levels in all mammals. They suggest that although sexual receptivity may be continuous in the human female (Nalbandov, 1964) 'heat' or heightened excitement may last for a limited period. This may be related to the release or activity of testosterone in the human female, as well as to oestrogen levels. Authors do not generally differentiate between an active or passive receptivity with the exception of Benedek \& Rubinstein (1942), who did so on the basis of unconscious dream material provided by patients under psycho-analysis. The most striking comparison with the human situation is the fact that although there is a "hyperresponsivity' of the uterus in oestrous cows, the uterine response in post-oestrous cows still appears after ejaculation (Hays \& VanDemark, 1953). Rodolfo (1934) also noted the lack of need for 'heat' to induce the boar to ejaculate into the sow.

\section{(b) Hormonal changes during the act of coitus}

Oxytocin. There is a considerable body of circumstantial evidence to support the theory that coitus is associated with the release of oxytocin into the bloodstream. It is further postulated that oxytocin causes uterine contractions which assist in sperm transport.

Harris (1947) suggested that coitus results in a nervous reflex release of oxytocic substance. Hays \& VanDemark (1953) reported that natural mating or manipulation of the reproductive organs of the lactating cow resulted in the release of oxytocin, while intravenous injection of oxytocin caused activity of the bovine uterus similar to that produced by natural mating. Hammond (1936) also observed that, in lactating mares, milk often flowed freely during mating. Harris \& Pickles (1953), Campbell \& Petersen (1953) and Masters \& Johnson (1966) reported the occurrence of milk ejection in the human during coitus, while Friberg (1953) reported anti-diuresis following human coitus, thus linking the release of posterior pituitary hormones with sexual activity. This topic has 
been well reviewed by Fitzpatrick $(1957,1966)$. The main criteria of an oxytocin-like response are milk ejection and an increase in uterine motility during mating and genital manipulation. Debackere \& Peeters (1960) and Debackere, Peeters \& Tuyttens (1961) conducted cross-circulation experiments in lactating ewes. Vaginal distension in one ewe resulted in increased intramammary pressure in the other ewe. This was matched by intravenous injection of 20 to $50 \mathrm{mU}$ of oxytocin. Similar experiments were conducted with a ram and a lactating ewe. When the seminal vesicles and ampullae of the male were stimulated manually per rectum, a milk-ejection response was observed in the ewe. Peeters, Debackere, Lauryssens \& Kuhn (1965) also reported an anti-diuretic effect of coitus in hydrated rams. Walmsley (1963) estimated the oxytocin content of blood taken from mares at the time of mating. She found $600 \mu \mathrm{U}$ of oxytocin in one animal and it is interesting that this was the only mare to show "an orgasm-like syndrome which is recognized not infrequently in mares" (Fitzpatrick, 1966). In human experiments, Fox \& Knaggs (1969), using a bioassay, have demonstrated the presence of milk-ejection activity (almost certainly due to oxytocin) in peripheral blood taken immediately after orgasm in the female, the levels being 13 to $16 \mu \mathrm{U} / \mathrm{ml}$ plasma. They were unable to show a similar occurrence in the male.

It is also of interest that Melin \& Kihlstrom (1963) reported that injections of oxytocin affected the sexual drive and number of ejaculates in rabbits. There was a significant decrease in the reaction time for the first ejaculate and the number of ejaculates as well as the sexual drive were significantly increased. Armstrong \& Hansel (1958) reported that oxytocin increased the testis weight in rabbits. They suggested that oxytocin stimulated the interstitial cells of the testis through a trophic action on the anterior pituitary, resulting in an increased secretion of interstitial-cell-stimulating hormone. This action of oxytocin was blocked by adrenaline, while a similar action by follicle stimulating hormone (FSH) was not blocked by adrenaline. Similar increases in testis weight were obtained by Shibushawa, Saito, Fukuda, Kawai, Yamada \& Tumizawa (1955), who also suggested that neurosecretion of oxytocin stimulated the release of pituitary gonadotrophins. They claimed that, in rats, dogs and humans, injections of oxytocin caused this release, as judged by the increased output of 17-ketosteroids. In rats, the testis size increased, as well as the size and number of tubules, and there was hypertrophy of the Leydig cells.

Catecholamines. It has been shown by Levi (1965) that there is an increase in the excretion of catecholamines in the human during emotional and sexual (non-coital) excitement. In addition, adrenaline was imputed by Genell (1939) to relax the cervix during oestrus in rats. Sawyer \& Markee (1959) found that adrenergic blockers interfered with parts of the coital and ovulatory processes in rabbits.

Gonadotrophins and testosterone. Saginor \& Horton (1968) reported that the act of copulation in male rabbits resulted in a striking rise in plasma testosterone level within $30 \mathrm{~min}$. A similar effect was noted with the mere presence of a female rabbit. It was also observed that, in contrast to the low basal androgen levels, the injection of human chorionic gonadotrophin or human menopausal gonadotrophin caused a twenty-five-fold and thirteen-fold rise in plasma 
testosterone, respectively, within $30 \mathrm{~min}$ of injection. They postulated a reflex release of gonadotrophin causing an increase in plasma testosterone during copulation. It is further suggested that the reflex release in the male may be compared with the reflex release of $\mathrm{LH}$ in the female which causes ovulation some $10 \mathrm{hr}$ after copulation. An attempt by these authors to repeat this experiment with human males yielded negative results. Haltmeyer \& Eik-Nes (1969) have also reported an increase in plasma testosterone in male rabbits some 45 mins after copulation. Reflex ovulation is seen in the rabbit, cat, mink and ferret. Eckstein \& Zuckerman (1955) and Zarrow, Campbell \& Clark (1968) have suggested that some spontaneous ovulators may ovulate in response to copulation and this may explain the wide variation of the day of conception in the human cycle (and hence the failure of the so-called 'safe-period'). Parkes (personal communication) has pointed out that there is a high conception rate in rape, where hormonal release, due to fear or anger, could produce reflex ovulation.

A recent study by Everitt \& Herbert (1969) suggests that adrenal androgens may play a significant rôle in the hormonal control of receptivity in female primates. This may offer an experimental explanation for the clinical finding that adrenalectomy combined with ovariectomy leads to a more consistent decrease in libido than ovariectomy alone (Waxenberg, Drellich \& Sutherland, 1959).

\section{EMISSION OF SOUND}

A description of the sound accompaniment of human coitus has been given by Pomeroy (1967) and Fox \& Fox (1969). Other species are known to emit sounds, though in the case of the cat, Elkan (1948) denies that they signal orgasm, suggesting that the wail of the cat is due to the pain caused by the penile barbs. Schaller (1963), during a field study of gorillas, described the vocal accompaniments to coitus in this species, comparing them to human sounds. Goodall (1965) also described the high pitched shrieks from female chimpanzees during and just after coitus, and Zumpe \& Michael (1968) described a 'lip-smacking' sound occurring at the point at which they thought orgasm was experienced in the female rhesus monkey. A similar sound in the male chimpanzee was noted by Goodall (1965).

In addition to the above criteria for orgasm, comparison may also be made of the qualitative and temporal aspects of the orgasmir response in the human and other mammalian species.

\section{QUALITATIVE ASPECTS OF THE ORGASMIC RESPONSE}

\section{Pelvic and abdominal straining and stretching, and vaginal activity}

The "strenuous abdominal muscle straining" accompanying what is believed to be orgasm in the bitch (Evans, 1933) may be compared with the description of abdominal straining given for the human female orgasm by Fox \& Fox (1969), and the contraction of the abdominal muscles reported by Masters \& Johnson (1966). Zumpe \& Michael (1968) noted "pelvic movements" in the 
female rhesus monkey continuing after her separation from the post-ejaculatory male. Rodolfo (1934) and Walton (1960) referred to the need for rhythmic pulsation of the artificial vagina to elicit seminal emission from the boar or dog. Walton also described contraction of the vagina in the mare, with, or shortly after, the withdrawal of the male's penis, and also at the time of coitus in the rat, mouse and guinea-pig. Another instance of active vaginal participation is given by Walton for the bitch, where he describes a vaginal constriction by muscular spasm which could obliterate the urethral lumen of the penis were it not protected by the os penis. Peeters et al. (1965) gave the following description of the effects of vaginal distension in their sheep cross-circulation experiments: "straining movements, strong contraction of the abdominal muscles and groaning. The balloon is often ejected from the vagina by these powerful straining movements. In cows and sheep in the upright position, vaginal distension produces pronounced arching of the back". It is noteworthy that these responses could be imitated by injecting oxytocin and the hormone was said to act after a latency of 25 to $35 \mathrm{sec}$. The stretching reflex in suckling mice has been suggested as a means of oxytocin assay by Vorherr, Kleeman \& Lehman (1967). We have also observed (unpublished) that a corrugating effect may reflect vaginal participation in human coitus. This corrugation of the vagina occurs before orgasm and supplies a frictional base for the penis, stimulating ejaculation. A similar effect may occur in the rat, since Genell (1939) depicted changes in the oestrous rat's vagina which caused it to corrugate. Masters \& Johnson (1966) have given a diagram of the 'orgasmic platform' of the vagina which also suggests corrugation.

\section{Male inertia and penile ejection}

Hartman \& Ball (1930), describing coitus in rats, wrote, "when ejaculation occurs, however, the last four or five pelvic thrusts are deeper than usual and the male lies on the back of the female, withdrawing slowly only at the end of several seconds. The deep final thrust, then, followed by a period of inertia on the part of the male lasting several seconds constitutes the sign of ejaculation. It is almost infallible ..." ". In the dog, as reported by Evans (1933), there is a period of inertia after ejaculation before separation occurs, and a description by Ivanov is quoted by him, in which fatigue, languor and heavy breathing are mentioned. These descriptions have much in common with the human pattern of response described by Fox \& Fox (1969), in which a period of inertia was noted in the male before the penis was ejected by the female during her orgasm. Whether active withdrawal by the male or ejection of the penis by the female occurs in other mammals is not known, nor is it known whether active withdrawal of the penis or expulsion by the female, is a common or rare form of termination of human coitus.

\section{Vaginal plugging}

This has been described by Florey \& Walton (1932) during their analysis of the differences between the guinea-pig and rabbit. They stated, "the presence of a copulation plug prevents the escape of the semen backwards and the whole force of contraction will be directed forwards into the uterus, (i.e. the rat and 
guinea-pig). A plug does not form in the rabbit". A similar state of affairs was noted in the boar by Rodolfo (1934), who stated that the last secretion of the boar during the sexual act formed a vaginal plug to force the semen to flow towards the Fallopian tubes. In many mammals, a copulatory plug results from coagulation of the semen and the species in which this is known to occur are listed by Hartman (1957) and Walton (1960). Human semen coagulates less firmly and later liquefies. We would suggest that a vaginal plug could be formed by coagulated semen in some species or by the detumescing penis in other species, including the human.

\section{Different orgasmic qualities}

We have noted, purely on a subjective basis, that there are differences in the kinds of human orgasm obtained as well as in the methods for obtaining them. Orgasm in the male can be obtained by psychological methods (fantasy), by friction, or by both together. In the female, friction seems more important for attaining orgasm. The sex differences in the relative importance of psychological factors in orgasm are underlined by the findings of Levi (1965), who reported that, in males, the secretion of adrenaline after watching pornographic films was increased by an average of $66 \%$, whilst in females it was frequently unchanged. Subjectively, the main emotion reported was sexual arousal, the self-rating scores being higher in the male group.

In addition, orgasm may be obtained by purely passive or purely active means, in both sexes. 'Passivity' may occur to the extent that orgasm may be obtained with no co-operation from the partner, and in fact, despite a decided reluctance to co-operate. 'Activity' implies a state of affairs in which a partner is instrumental in inducing his or her own orgasm.

Qualitative differences between a more active and a more passive type of female orgasm have been described frequently in the much debated controversy over 'vaginal' and 'clitoral' orgasm, and have been reviewed by Brown (1967). Masters \& Johnson (1966) were unable to find a physiological basis for such differences. On a subjective basis, differences have been considered by Payne (1936), O'Hare (1951) and Fox \& Fox (1969). The subject has been considered by Campbell \& Petersen (1953), who suggested a physiological basis for qualitative differences in female orgasm, with release of oxytocin thought to be present in one kind, i.e., " . . . there was observed a correlation between the fullness of the sexual response and the let-down phenomenon, it being much more marked when the woman felt a greater sexual response had been achieved" (they were considering milk-ejection during orgasm in lactating women). In support of this, we have observed (unpublished) that the milk ejection response did not occur at each orgasm of a lactating female (studied in connection with oxytocin release, Fox \& Knaggs, 1969). In fact, the response appeared most frequently when there was a noticeable amount of the psychological component of orgasm as opposed to the purely frictional.

That ejaculation can be stimulated by purely frictional means in non-human mammals is also seen in the literature on artificial insemination, with experimental studies by Pussep (1922) in the dog, Rodolfo (1934) in the boar, and summaries by Walton (1960) and Parkes (1960b). 


\section{TEMPORAL ASPECTS OF ORGASMIC RESPONSE}

One gains the impression, at least from the semi-scientific literature, that simultaneous male and female orgasm is desirable, if not biologically important, in the human. Our own studies have enabled us to observe that there was a temporal lag of some $30 \mathrm{sec}$ (range 15 to $60 \mathrm{sec}$ ) between ejaculation and female orgasm. This was a constant finding and corresponds with the kind of latency found for the bitch's climactic response (Pussep, 1922; Evans, 1933), following ejaculation, and the cow's uterine response (Hays \& VanDemark, 1953). In the rhesus monkey, however, consummatory responses may be simultaneous (Zumpe \& Michael, 1968) since the female's clutching reaction slightly precedes ejaculation but, as there may well be some independence of the clutching reaction and orgasm, this observation awaits confirmation by alternative orgasmic criteria. We have observed that the clutching reaction in the human may be independent of orgasm, and that orgasm may be interrupted after clutching has occurred. Studies from Melanesia by Malinowski (1929) and Davenport (1967) have reported simultaneous orgasm amongst the natives, while Mead (1961) stated that orgasm is a rare occurrence amongst the females of primitive tribes.

\section{GONGLUSIONS}

The four criteria for orgasm postulated here can be traced through the mammalian kingdom to a greater or lesser extent. In attempting to highlight the similarities between human and other mammalian reproductive processes, we are not unaware of the many and obvious differences. Our justification is the lack of knowledge that exists on so fundamental a topic as the physiology of human coitus. This deficiency is largely due to the intimate nature of the subject, which presents great problems to the experimenter and prevents large-scale replication. It is to be hoped, in view of the present world-wide concern with over-population and unplanned parenthood, that modern techniques will enable researchers to gain insight into the processes which lead to conception. It is the authors' opinion that at present the most obvious line of advance must depend on individual experimenters who are prepared to publish their findings.

\section{ACKNOWLEDGMENT}

We are greatly indebted to Professor Sir Alan Parkes for reading the manuscript, and for his helpful suggestions and encouragement. This paper forms part of an M.D. thesis for the University of Cambridge.

\section{REFERENCES}

AKESTER, R. \& INKSTER, I. J. (1961) Cine-radiographic studies of the genital tract of the rabbit. 7. Reprod. Fert. 2, 507.

Armstrong, D. T. \& Hansel, W. (1958) Effects of hormone treatment on testes development and pituitary function. Int. F. Fert. 3, 296.

Bartlett, R. G., JR (1956) Physiologic responses during coitus. F. appl. Physiol. 9, 469.

Benedek, T. \& Rubinstein, B. B. (1942) The sexual cycle in women. Psychosom. Med. Monogr. Suppl. 3, Nos. 1 and 2 . 
Bickers, W. \& MAIN, R. S. (1941) Patterns of uterine motility. In normal, ovulatory and anovulatory cycles, after castration, coitus and missed abortion. . clin. Endocr. 1, 992.

Bishop, D. W. (1961) Biology of spermatozoa. In: Sex and Internal Secretions, 3rd edn, pp. 707-796. Ed. W. G. Young. Williams \& Wilkins, Baltimore.

BoAs, E. P. \& Goldschmidt, E. F. (1932) The heart rate. Thomas, Springfield, Ill.

Brown, D. G. (1967) Female orgasm and sexual inadequacy. In: An Analysis of Human Sexual Response, pp. 125-174. Eds. Ruth and Edward Brecher. Deutsch, London.

Campbell, B. \& Petersen, W. E. (1953) Milk 'let-down' and the orgasm in the human female. Hum. Biol. 25, 165.

Garleton, H. M. \& Florey, H. (1931) Birth control studies. I. On the ingress of semen into the uterus during coitus. 7. Obstet. Gynec. Brit. Emp. 38, 550.

Colmeiro-LAForer, C. (1953) Lack of orgasm as a cause of sterility. In: Sex, Society and the Individual, pp. 163-170. Eds. A. P. Pillay and A. Ellis. Int. J. Sex. Bombay.

Davenport, W. (1967) Sexual patterns in a south west Pacific society. In: An Analysis of Human Sexual Response, pp. 175-200. Eds. Ruth and Edward Brechner. Deutsch, London.

Debackere, M. \& Peeters, G. (1960) The influence of vaginal distension on milk-ejection and diuresis in the lactating cow. Archs int. Pharmacodyn. Ther. 123, 462.

Debackere, M., Peeters, G. \& Tuyttens, N. (1961) Reflex release of an oxytocic hormone by stimulation of the genital organs in male and female sheep studied by a cross-circulation technique. 7. Endocr. 22, 321.

Eckstein, P. \& Zuckerman, S. (1955) Reproduction in mammals. Mem. Soc. Endocr. 4, 114.

EgLi, G. E. \& Newton, M. (1961) The transport of carbon particles in the human female reproductive tract. Fert. Steril. 12, 151.

ElKan, E. (1948) Evolution of female orgiastic ability-a biological survey. Marr. Hyg. 2, 1, and Int. 7. Sex. 2, 1 .

Evans, E. I. (1933) The transport of spermatozoa in the dog. Am. 7. Physiol. 105, 287.

Everit, B. H. \& Herbert, J. (1969) Adrenal glands and sexual receptivity in female rhesus monkeys. Nature, Lond. 222, 1065.

FitzPatrick, R. J. (1957) On oxytocin and uterine function. In: The Neurohypophysis, pp. 203-220. Ed. H. Heller. Butterworths, London.

Fitzpatrick, R. J. (1966) The posterior pituitary gland and the female reproductive tract. In: The Pituitary Gland, pp. 453-504. Eds. G. W. Harris and B. T. Donovan. Butterworths, London.

Florey, H. \& Walton, A. (1932) Uterine fistula used to determine the mechanism of ascent of the spermatozoa in the female genital tract. 7. Physiol., Lond, 74, 5P.

Ford, C. S. \& BeAch, F. A. (1951) Patterns of sexual behaviour. Harper, New York.

Fox, C. A. \& Fox, B. (1967) Uterine suction during orgasm. Br. med. 7. i, 300.

Fox, C. A. \& Fox, B. (1969) Blood pressure and respiratory patterns during human coitus. 7 . Reprod. Fert. 19, 405.

Fox, C. A. \& KNaggs, G. S. (1969) Milk-ejection activity (oxytocin) in peripheral venous blood in man during lactation and in association with coitus. J. Endocr. 45, 145.

Fox, C. A., WolfF, H. S. \& BAKer, J. A. (1970) Measurement of intra-vaginal and intra-uterine pressures during human coitus by radio-telemetry. F. Reprod. Fert. 22, 243.

FriberG, O. (1953) The anti-diuretic effect of coitus in human subjects. Acta endocr., Copenh. $12,193$.

GENELL, S. (1939) Experimental investigations on the muscular functions of the vagina and the uterus in the rat. Acta abstet. gynec. scand. 19, 113.

Goodall, J. (1965) Chimpanzees of the Gombe Stream Reserve. In: Primate Behaviour. Field Studies of Monkeys and Apes, pp. 425-473. Ed. I. DeVore. Holt, Rinehart \& Winston, New York.

Grafenberg, E. (1950) The role of urethra in female orgasm. Int. F. Sex. 3, 145.

Haltmeyer, G. C. \& Eik-Nes, K. B. (1969) Plasma levels of testosterone in male rabbits following copulation. J. Reprod. Fert. 19, 273.

Hammond, J. (1936) The physiology of milk and butter fat secretion. I. Milk pressure in the udder. Vet. Rec. 16, 519.

Hammond, J. \& AsDell, S. A. (1926) The vitality of the spermatozoa in the male and female reproductive tract. F. exp. Biol. 4, 155.

Harris, G. W. (1947) The innervation and actions of the neurohypophysis. An investigation using the method of remote-control stimulation. Phil. Trans, R. Soc. B, 232, 385.

Harris, G. W. \& Pickles, V. R. (1953) Reflex stimulation of the neurohypophysis (posterior pituitary gland) and the nature of posterior pituitary hormone(s). Nature, Lond. 172, 1049.

Hartman, G. G. (1957) How do sperms get into the uterus? Fert. Steril. 8, 403.

Hartman, C. G. \& Ball, J. (1930) On the almost instantaneous transport of spermatozoa through the cervix and the uterus of the rat. Proc. Soc. exp. Biol. Med. 28, 312.

HaYs, R. L. \& VANDEMark, N. L. (1953) Effect of stimulation of the reproductive organs of the cow on the release of an oxytocin-like substance. Endocrinology, 52, 634 . 
Heller, C. G., Laidlaw, W. M., Harvey, H. T. \& Nelson, W. O. (1958) Effects of progestational compounds on the reproductive processes of the human male. Ann. N.Y. Acad. Sci. 71, 649.

Kinsey, A. C., Pomeroy, W. B., Martin, C. E. \& Gebhard, P. H. (1953) Sexual behaviour in the human female, pp. 600-601. W. B. Saunders, Philadelphia and London.

Klumbies, G. \& KLeinsorge, H. (1950) Circulatory dangers and prophylaxis during orgasm. Int. $\mathcal{J}$. Sex. 4, 61 .

Krehbiel, R. H. \& Carstens, S. G. P. (1939) Roentgen studies of the mechanism involved in sperm transport in the female rabbit. Am. F. Physiol. 125, 571.

Levi, L. (1965) The urinary output of adrenaline and noradrenaline during pleasant and unpleasant emotional states. Psychosom. Med. 27, 80.

Malinowski, B. (1929) The sexual life of savages in north western Melanesia. Liveright, New York.

Masters, W. H. \& Johnson, V. E. (1961) The physiology of the vaginal reproductive function. West 7. Surg. Obstet. Gynec. 69, 105.

Masters, W. H. \& Johnson, V. E. (1966) Human sexual response. Churchill, London.

MEAD, M. (1961) Cultural determinants of sexual behaviour. In: Sex and Internal Secretions, 3rd edn, pp. 1433-1479. Ed. W. C. Young. Williams \& Wilkins, Baltimore.

Melin, P. \& Kinlstrom, J. E. (1963) Influence of oxytocin on sexual behaviour in male rabbits. Endocrinology, 73, 433.

Mendelsohn, M. (1896) Ist das Radfahren also ein gesundheitsgemässe Uebung anzusehen und aus ärtzlichen Gesichtspunkt zu empfehlen. Dt. med. Wschr. 24, 381.

Michael, R. P., Herbert, J. \& SAayman, G. (1966) Loss of ejaculation in male rhesus monkeys after administration of progesterone to their female partners. Lancet, i, 1015.

Michael, R. P. \& Zumpe, D. (1970) Rhythmic changes in the copulatory frequency of rhesus monkeys (Macaca mulatta) in relation to the menstrual cycle, and a comparison with the human cycle. 7. Reprod. Fert. 21, 199.

Millar, R. (1952) Forces observed during coitus in thoroughbreds. Aust. vet. $7.28,127$.

Nalbandov, A. V. (1964) Reproductive physiology, 2nd edn. W. H. Freeman, San Francisco and London.

Noyes, R. W., Adams, C. E. \& Walton, A. (1958) Transport of spermatozoa into the uterus of the rabbit. Fert. Steril. 9, 288.

O'HARe, H. (1951) Vaginal versus clitoral orgasm. Int. J. Sex. 4, 243.

PARkes, A. S. (1960a) The biology of spermatozoa and artificial insemination. VI: Transport, selection and fate of spermatozoa in the female mammal. In: Marshall's Physiology of Reproduction, 3rd edn, Vol. 1, Part 2, pp. 234-242. Ed. A. S. Parkes. Longmans, London.

PARKes, A. S. (1960b) The biology of spermatozoa and artificial insemination. I: Semen collection and artificial insemination. In: Marshall's Physiology of Reproduction, 3rd edn, Vol. 1, Part 2, pp. 161-181. Ed. A. S. Parkes. Longmans, London.

Payne, S. (1936) A concept of femininity. Br. 7. med. Psychol. 15, 18.

Peeters, G., Debackere, M., Lauryssens, M. \& Kuhn, E. (1965) Studies on the release of oxytocin in domestic animals. In: Advances in Oxytocin Research, pp. 75-80. Ed. J. M. H. Pinkerton. Pergamon Press, Oxford.

Pomeroy, W. B. (1967) The Masters-Johnson report and the Kinsey tradition. In: An Analysis of Human Sexual Response, pp. 111-123. Eds. Ruth and Edward Brecher. Deutsch, London.

Pussep, L. M. (1922) Der Blutkreislauf im Gehirn beim Koitus. In: Sexualreform und Sexualwissenschaft. I. Internationalen Tagung für Sexualreform auf sexualwissenschaftlicher Grundlage in Berlin. pp. 61-85. Ed. A. Weil. Püttmann, Stuttgart.

Reynolds, S. R. M. (1930) Studies in the uterus-a method of recording uterine activity in chronic experiments in unanaesthetized animals. Am. F. Physiol. 92, 420.

Rodolfo, A. (1934) The physiology of reproduction in swine. II. Some observations on mating. Philipp. 7. Sci. 55, 13 .

SAGinor, M. \& Horton, R. (1968) Reflex release of gonadotropin and increased plasma testosterone concentration in male rabbits during copulation. Endocrinology, 82, 627.

SAWYer, C. H. \& MARkeE, J. E. (1959) Estrogen facilitation of release of pituitary ovulating hormone in the rabbit in response to vaginal stimulation. Endocrinology, 65, 614 .

Schaller, G. B. (1963) The mountain gorilla. Ecology and behaviour, pp. 214-215; 283-284. University of Chicago Press.

Shibushawa, K., Saito, S., Fukuda, K., Kawai, T., Yamada, J. \& Tumizawa, K. (1955) Neurosecretion of oxytocin stimulates the release of the pituitary gonadotrophin. Endocr. jap. 2, 183.

Trapl, J. (1943) Neue Anschauungen über den Ei-und Samentransport in den inneren Geschlechtsteilen der Frau. Zentbl. Gynäk. 67, 547.

Udry, J. R. \& Morris, N. M. (1968) Distribution of coitus in the menstrual cycle. Nature, Lond. 220, 593.

VanDemark, N. L. \& Hays, R. L. (1952) Uterine motility responses to mating. Am. J. Physiol. $170,518$. 
VANDemark, N. L. \& Moelier, A. N. (1951) Speed of spermatozoan transport in reproductive tract of estrous cow. Am. J. Physiol. 165, 674.

von Amersbach, R. (1930) Sterilität und Frigidität. Münch. med. Wschr. 77, 225.

VorherR, H., KLEEMAN, C. R. \& LeHMAN, E. (1967) Oxytocin-induced stretch reaction in suckling mice and rats. Endocrinology, 81, 711.

WALMsLey, G. F. (1963) The concentration of oxytocin in blood in relation to reproduction. M.Sc. thesis, University of Bristol.

Walton, A. (1930) On the function of the rabbit cervix during coitus. F. Obstet. Gynaec. Brit. Emp. 37,92 .

Walton, A. (1960) Copulation and natural insemination. In: Marshall's Physiology of Reproduction, 3rd edn, Vol. 1, Part 2, pp. 130-160. Ed. A. S. Parkes. Longmans, London.

Waxenberg, S. E., Drelifich, M. G. \& Sutherland, A. M. (1959) The role of hormones in human behaviour. I. Changes in female sexuality after adrenalectomy. F. clin. Endocr. Metab. 19, 193.

Yamanaka, H. S. \& Soderwall, A. L. (1960) Transport of spermatozoa through the female genital tract of hamsters. Fert. Steril. 2, 470.

Young, W. G. (1961) The hormones and mating behaviour. In: Sex and Internal Secretions, 3rd edn, pp. 1173-1239. Ed. W. G. Young. Williams \& Wilkins, Baltimore.

Young, W. G. \& GRUNT, J. A. (1951) The pattern and measurement of sexual behaviour in the male guinea-pig. F. comp. physiol. Psychol. 44, 492.

Zarrow, M. X., Campbell, P. S. \& Clark, J. H. (1968) Pregnancy following coital-induced ovulation in a spontaneous ovulator. Science, N.Y. 159, 329.

Zumpe, D. \& MichaEL, R. P. (1968) The clutching reaction and orgasm in the female rhesus monkey (Macaca mulatta). F. Endocr. 40, 117. 